\title{
CEDAW AND THE SECURITY COUNCIL: ENHANCING WOMEN'S RIGHTS IN CONFLICT
}

\author{
Catherine O'Rourke* and Aisling Swaine**
}

\begin{abstract}
The proliferation of legal and normative standards regulating women's rights in conflict has been accompanied by concerns about their efficacy. The article examines the activities of the CEDAW Committee and the UN Security Council and considers how synergies might be advanced. The article finds that, while the Security Council has unique authority over UN system activities, sanctions and peacekeeping, the CEDAW Committee - as a human rights treaty monitoring bodypossesses the more effective system of State accountability and the more robust commitment to women's equality and rights. The article proposes measures for the optimum interaction between both institutions in order to maximize overall accountability for women's rights in conflict.
\end{abstract}

Keywords: accountability, armed conflict, CEDAW, feminism, fragmentation, peace and security, United Nations Security Council, women, women's rights.

\section{INTRODUCTION}

Given the formerly prevailing 'silence' of international law on women's status and rights in armed conflict, ${ }^{1}$ the proliferation of legal standards and obligations in recent years offers promise. On 30 October 2013, for example, the monitoring body (the 'Committee') of the Convention on the Elimination of All Forms of Discrimination against Women ('the Convention') adopted General Recommendation Number 30 (GR30) on the rights of women in conflict prevention, conflict and post-conflict situations. ${ }^{2}$ On the same day, the United Nations Security Council (UNSC) adopted Resolution 2122 on women's leadership in peacebuilding. ${ }^{3}$ This was the eighth resolution under its Women, Peace and Security (WPS) agenda, inaugurated in 2000 by the

* Senior Lecturer, Transitional Justice Institute, Ulster University, cf.orourke@ulster.ac.uk.

** Assistant Professor in Gender and Security, Department of Gender Studies, London School of Economics and Political Science, a.swaine@1se.ac.uk.

1 J Gardam, 'Women and the Law of Armed Conflict: Why the Silence?' (1997) 46 ICLQ 55.

2 Committee for the Elimination of All Forms of Discrimination against Women (CEDAW), 'General Recommendation No. 30 on Women in Conflict Prevention, Conflict and Post-Conflict Situations' (18 October 2013) UN Doc CEDAW/C/GC/30 [hereafter GR30].

${ }^{3}$ UNSC Res $2122(2013)$ S/RES2122/2013. 
adoption of Resolution 1325.4 We can now credibly point to a corpus of international law regulating the treatment of women in armed conflict. This is attributable to a considerable growth in the activity of feminist lawyers, diplomats and pressure groups in response to the practical needs of specialization around the treatment of women in conflict-affected settings. It evidences a recognition that, to quote Judge Weeramantry's dissent in the Nuclear Weapons case, 'complex problems have ramifications in many specialized directions'. 5 The challenge of guaranteeing women's rights in conflict is indeed a complex one.

That two regimes of international law are now engaged in the same thematic area is, of course, not unique to women's rights in conflict. The increase in overlapping standards and obligations created by the monitoring and interpretative activities of the CEDAW Committee and the development of WPS resolutions by the UNSC is an example of much broader trends in the diversification and expansion of international law. The view of the International Law Commission is that such fragmentation 'create[s] the danger of conflicting and incompatible rules, principles, rule-systems and institutional practices'. ${ }^{6}$ The phenomenon has given rise to significant scholarly concern and doctrinal efforts to determine primacy in the context of overlapping international norms. While the operation of both the Convention and the WPS agenda has generated extensive scholarly engagement, specific feminist consideration of fragmentation in international law per se has been notably sparse. ${ }^{7}$ The specific institutional implications of manifold overlapping gender equality norms and obligations in international law is, therefore, under-examined.

Initial feminist interventions into the field of international law identified a 'masculine world', with reinforcing organizational and normative structural factors that excluded women from its practice and women's lives from its areas of concern. ${ }^{8}$ By contrast, contemporary regime activity concerning women's rights in conflict engages international human rights law and the UNSC. In addition, States have agreed to limit the lawful conduct of armed conflict — including against female combatants and civilians - under international humanitarian law $^{9}$ and, under international criminal law,

${ }^{4}$ UNSC Res 1325 (2000) S/RES1325/2000.

${ }_{6}^{5}$ Use of Nuclear Weapons [1999] (I) ICJ Rep 66, 151.

${ }^{6}$ ILC, 'Fragmentation of International Law: Difficulties Arising from the Diversification and Expansion of International Law' (13 April 2006) UN Doc A/CN.4/L.682 para 14.

7 Isolated examples include F Ní Aoláin, 'International Law, Gender Regimes and Fragmentation: 1325 and Beyond' in CM Bailliet (ed), Non-State Actors, Soft Law and Protective Regimes: From the Margins (Cambridge University Press 2012); and C O'Rourke, 'Feminist Strategy in International Law: Understanding Its Legal, Political and Normative Dimensions' (forthcoming 2017) 28 EJIL.

${ }^{8}$ H Charlesworth, C Chinkin and S Wright, 'Feminist Approaches to International Law' (1991) 85 AJIL 613.

${ }_{9}$ See generally International Committee of the Red Cross, Women Facing War: ICRC Study on the Impact of Armed Conflict on Women (Geneva 2001). 
established international criminal jurisdiction over individuals bearing greatest responsibility for the most serious violations of these laws. ${ }^{10}$ The relevant laws were developed at different times by different groups of States. They are motivated by divergent priorities and implemented by separate institutions with widely varying powers of monitoring and enforcement. The contemporary domain, with its tapestry of normative and legal commitments across regimes of international law, therefore posits a more subtle and complex set of challenges for feminist analysis. In a relatively rare intervention on the theme of fragmentation, Ní Aoláin has sounded a feminist doctrinal alarm that increase in attention to the WPS agenda by advocates and State actors has deprioritized monitoring and compliance with human rights obligations. This deprioritization is reflected in particular, she argues, with respect to obligations under the International Covenant on Economic, Social and Cultural Rights. ${ }^{11}$ Charlesworth and Chinkin question the efficacy of vastly increased normative activity addressing women in armed conflict; they express concerns about progress being more ostensible than real. ${ }^{12}$ Aligned to such concerns, feminist doctrinal critique about the overwhelmingly 'soft' nature of feminist-informed developments in international law has a comparatively long lineage. ${ }^{13}$ More broadly, feminist work that implicates fragmentation in international law belongs to more fundamental feminist questioning of positing 'more or better law' as the solution to complex social and political problems of gender inequality.

This article takes as its focus the interaction between the Convention and the UNSC WPS resolutions for a number of linked reasons. Firstly, the pursuit of productive interactions between the Convention and the UNSC WPS activities has received significant political and policy impetus in recent years. It was inaugurated initially by the CEDAW Committee's landmark GR30, which expressly addresses the relationship between the Convention and the WPS Resolutions. In response, UN Women, the entity leading the UN's policy and programming on women's rights, commissioned a Guidebook for States and civil society on the General Recommendation and its relationship to the WPS resolutions. ${ }^{14}$ Together, these initiatives informed a broadening of relevant civil society activity, with considerable evidence of the WPS advocacy community taking greater interest in the Convention procedures. ${ }^{15}$ Further, the United Nations 2015 Global Study on the Implementation of Resolution 1325

\footnotetext{
10 See generally S Brammertz and M Jarvis (eds), Prosecuting Conflict-Related Sexual Violence at the ICTY (Oxford University Press 2016).

$11 \mathrm{Ni}$ Aolain (n 7).

12 H Charlesworth and C Chinkin, 'An Alien's Review of Women and Armed Conflict' (2015) Regnet Working Paper No. 73, 1 .

${ }_{13} \mathrm{H}$ Charlesworth, 'The Unbearable Lightness of Customary International Law' (1998) 92 AJIL Proceedings 44.

${ }^{14}$ C O'Rourke and A Swaine, Guidebook on CEDAW General Recommendation No. 30 and the UN Security Council Resolutions on Women, Peace and Security. (UN Women 2015).

${ }_{15} \mathrm{See}$, for example, Global Network of Women Peacebuilders, <http://gnwp.peacegeeks.org/ tags/cedaw $>$.
} 
dedicated a full chapter to the issue of "linkages between human rights mechanisms and the UNSC resolutions on Women, Peace and Security' and made specific recommendations concerning the need for improved synergies between the two. ${ }^{16}$ In December 2016 an 'Arria Formula Meeting on Linkages between UNSC Resolution 1325 and CEDAW General Recommendation Number 30' was held between the UNSC and members of the CEDAW Committee in the UN Headquarters in New York. ${ }^{17}$ Together, these policy, political and advocacy developments signal very significant interest in current and potential interactions between the Convention and the WPS resolutions. In addition to contributing to broader scholarly analysis of fragmentation, this article seeks to inform contemporary debates in policy and practice by offering the first extended scholarly treatment of the interactions between the Convention and the WPS resolutions on the issue of women's rights in conflict.

This article is unique in its focus on the practical and institutional question of whether and how the Convention and WPS activities - and their interactionsadvance accountability under international law for the rights of women in conflict. We therefore follow the 'institutional perspective' of Young and others, ${ }^{18}$ by considering the functional strengths of institutional activity on women's rights in conflict under the CEDAW Committee - as an institution of international human rights law - and the UNSC, respectively. The article provides the first systematic review of both CEDAW Committee activities on women's rights in conflict and the procedural workings of the UNSC's WPS activities. Further, we consider the practical incidences of interaction between the institutions. The analysis extends to a consideration of how the CEDAW Committee and UNSC should interact in order to maximize accountability for women's rights in conflict.

The priorities that motivate our inquiry are twofold. First, from an institutional perspective, we explore the extent to which progressive normative development on women's rights in conflict is accompanied by meaningful accountability. Concerns about accountability emerge from the shadowy legal status attached to the normative developments in question. This is a familiar problem to feminists working in the terrain of public international law. ${ }^{19}$ While the CEDAW Committee operates - uniquely - as an independent group of experts in women's human rights contributing to treaty monitoring and interpretation, it operates at one remove from State consent. The UNSC is not a representative body and, as a result, any legislative or quasi-legislative action can lack legitimacy and acceptability to

\footnotetext{
16 United Nations, Preventing Conflict, Transforming Justice, Securing the Peace: A Global Study on the Implementation of UNSC Resolution 1325 (2015) 346-66

17 On 'arria formula' meetings, see further: United Nations, The Security Council: Working Methods Handbook (2012) 80-9.

18 MA Young, Trading Fish, Saving Fish: The Interaction between Regimes in International Law (Cambridge University Press 2011) 10.
} 
non-members. ${ }^{20}$ Further, the UNSC's authority to engage in law-making activity is highly contested. ${ }^{21}$ Nevertheless, since 1990 , the UNSC has been found to increasingly engage in this manner of law-making and norm development. $^{22}$ It has done so without any accompanying system for maintaining broad accountability from UN member States.

Secondly, we consider ways to counter the thematic narrowing of women's rights in conflict, given evidence of increasing securitization of women's rights emerging from the UNSC's WPS agenda. ${ }^{23}$ Women's rights issues - such as violence against women - have become defined and addressed according to the UNSC's mandate to maintain international peace and security, rather than in line with the experiences of women and girls and the fulfilment of their rights. ${ }^{24}$ Further, whereas the CEDAW Committee has adopted a broad understanding of 'conflict' - which includes protracted and low-intensity civil strife, ethnic and communal violence and States of emergency ${ }^{25}$ - the UNSC has largely resisted such a broad definition, with some permanent members arguing that the WPS resolutions apply only to the country situations on the agenda of the UNSC. ${ }^{26}$ In order to counter thematic narrowing of women's rights in conflict, we see potential in the women's human rights mandate of the CEDAW Committee. The institutional and thematic challenges combine to give greater urgency to efforts to enhance the relationship between both institutions.

We argue that, while the CEDAW Committee is singularly capable of pursuing meaningful State accountability within a human rights framework, the UNSC has unique capacities in respect of UN system activities, and multilateral responses to threats to international peace and security, such as UN peacekeeping, addressing non-State actors, a sanctions regime and country-specific resolutions. The article begins by mapping the emergence of institutional activity on the thematic area of women's rights in conflict by both the CEDAW Committee and the UNSC. It reviews the accountability mechanisms and activity to date on women's rights in conflict within the respective institutions. The article considers the current institutional interactions between the CEDAW Committee and the UNSC on women's rights in conflict and how this relationship might be enhanced to improve overall accountability for women's rights in conflict. The article argues that there are opportunities for improved complementarity between the CEDAW Committee, as an institution of the human rights system, and the UNSC. The

20 A Boyle and C Chinkin, The Making of International Law (Oxford University Press 2007)

114. 21 PC Szasz, 'The Security Council Starts Legislating' (2002) 96(4) AJIL901-5.

22 ibid. Boyle and Chinkin (n 20) 114-15, 229-32.

23 See, for example, F Ní Aoláin, 'The 'War on Terror' and Extremism: Assessing the Relevance of the Women, Peace and Security Agenda' (2016) 92 International Affairs 275.

24 D Otto, 'The Exile of Inclusion: Reflections on Gender Issues in International Law over the Last Decade' (2009) 10 Melbourne Journal of International Law $11 . \quad{ }^{25}$ GR30 (n 2) para 4.

26 See further text at (nn 95 and 151-153). 
article concludes that this complementarity is best pursued through ongoing processes of cross-regime dialogue, to facilitate practical cooperation, and inter-regime accountability, in which each regime seeks to hold the other to account for its activities on women's rights in conflict.

II. THE EMERGENCE OF FRAGMENTED INSTITUTIONAL ACTIVITY ON WOMEN'S RIGHTS IN CONFLICT

Thematic activity on women's rights in conflict has emerged from both the CEDAW Committee and the UNSC, though not contemporaneously. The divergent timelines reflect differences between the institutional mandates of the UNSC and other organs of the UN. The relatively late arrival of the UNSC to the issue of women's rights in conflict, as compared to the CEDAW Committee, can be attributed to a number of linked factors that this section discusses in depth.

\section{A. The CEDAW Committee and Women's Rights in Conflict}

The breadth of the contemporary CEDAW Committee's activity on women's rights in conflict was not necessarily to be predicted from its institutional origins in the UN human rights system. The UN's human rights activity emerges principally from Article 1 of the UN Charter, which lists 'promoting and encouraging respect for human rights' as one of the foundational objectives of the institution. ${ }^{27}$ In terms of the allocation of institutional responsibility for the implementation of these actions and objectives, the Charter envisages a role for the General Assembly in commissioning studies and making recommendations to assist in the realization of human rights. ${ }^{28}$ It also envisages a lead institutional role for the Economic and Social Council (ECOSOC) to make and initiate studies and recommendations, ${ }^{29}$ but also critically to set up commissions 'for the promotion of human rights' ${ }^{30}$ From this latter ostensibly modest provision, an expansive institutional architecture for the protection and promotion of human rights has emerged. The critical early development for the protection of women's human rights was the ECOSOC resolution establishing the Commission on Human Rights, to lead intergovernmental developments on human rights, and the Commission on the Status of Women, to lead intergovernmental developments on women's equality. ${ }^{31}$ These distinct elements of the human rights system cooperate in

\footnotetext{
27 Charter of the UN (24 October 1945) 1 UNTS XVI. Further, arts 55 and 56 pledge member States to take cooperative action to promote universal respect and observance of human rights.

28 ibid art 13(1). This should be read as complementary to its art 10 mandate to discuss any matter dealt with by the Charter and to make recommendations to States.

${ }^{29}$ Charter of the UN (n 27) art 63. $\quad 30$ ibid art 68.

31 ECOSOC resolution establishing the Commission on Human Rights and the Subcommission on the Status of Women, ECOSOC Res 11 (21 June 1946) UN Doc E/RES/2/11.
} 
the development and adoption of treaties for the enhanced protection of human rights.

The idea of a women's rights treaty was given initial institutional impetus by the General Assembly Declaration on the Elimination of Discrimination against Women in $1967 .{ }^{32}$ The working draft of the treaty emerged firstly from the Commission on the Status of Women, was further scrutinized by the Third Committee of the General Assembly (Social Affairs) and was ultimately adopted and opened for signature by resolution of the General Assembly. ${ }^{33}$ The adoption of the Convention in 1979 signalled an important acknowledgement by the international community, and more particularly by the UN human rights system, of the deficiencies of the so-called 'mainstream' human rights instruments to protect and promote the rights of women. ${ }^{34}$ The novelty of the Convention lay in its specificity to the lives of women and its transcendence of the boundaries traditionally established by human rights treaties, in particular between public and private spheres. ${ }^{35}$ Much more than its symbolic importance, however, the entry into force of the Convention in 1981 established a treaty-based system of State accountability ${ }^{36}$ for an enumerated list of women's human rights, involving a periodic review of State compliance ${ }^{37}$ by an independent committee of experts. ${ }^{38}$ The Committee has established itself as the key institution advancing feminist-informed normative and legal developments on women's rights under international law. ${ }^{39}$

The Convention does not specify its application to armed conflict-in contrast, for example, to the Convention on the Rights of the Child. ${ }^{40}$ Further, its provisions do not specifically address the needs and rights of women that prevail in conflict-affected settings. Nevertheless, the Convention does not permit derogations and the Committee has consistently affirmed the

32 UNGA Res 2263 (XXII) (7 November 1967).

33 UNGA Res 34/180 (18 December 1979).

${ }^{34}$ M Freeman, C Chinkin and B Rudolf (eds), The UN Convention on the Elimination of All Forms of Discrimination against Women: A Commentary (Oxford University Press 2012) 5-7.

35 Convention on the Elimination of All Forms of Discrimination against Women (adopted 18 December 1979, entered into force 3 September 1981) 1249 UNTS 13 (CEDAW) art 1.

${ }^{36} \mathrm{We}$ adopt here the meaning of 'accountability' as it conventionally used in respect of the CEDAW Convention. To quote Rebecca Cook:

Legal responsibility denotes liability for breach of the law, but accountability is a wider concept that requires a state to explain an apparent violation and to offer an exculpatory explanation if it can ... States are seldom held responsible for ignoring their more international obligations to respect women's human rights, but may more often be called to account for the status of women in their territory.

See further R Cook, 'State Accountability under the Convention on the Elimination of All Forms of Discrimination against Women' in R Cook (ed), Human Rights of Women: National and International Perspectives (University of Pennsylvania Press 1994) 228-56. See also Freeman et al. (n 34) discussing 'accountability' under the Convention.

37 CEDAW (n 35) art 18.

38 ibid art 17.

39 Freeman, Chinkin and Rudolf (n 34) 13.

40 Convention on the Rights of the Child (adopted 20 November 1989, entry into force 2 September 1990) 1577 UNTS 3 (CRC) art 38. 
Convention's application to conflict, civil strife and public emergency. ${ }^{41}$ The adoption by the Committee of GR30 on the rights of women in conflict prevention, conflict and post-conflict situations therefore arose from the recognized silences of the Convention in specifically addressing challenges to women's rights in such settings. ${ }^{42}$ The bulk of GR30 is dedicated to articulating the ways in which the rights guaranteed under the Convention are impacted by conflict, specifically the prohibition of discrimination in law, policy and custom; ${ }^{43}$ the obligation on States to challenge discriminatory social and cultural patterns; ${ }^{44}$ the prohibition on trafficking $;{ }^{45}$ the right to political participation in domestic and international affairs; 46 access to education, employment, health; $;{ }^{47}$ the rights of rural women; ${ }^{48}$ right to nationality $;{ }^{49}$ right to equality in marriage and family relations; $; 0$ and the right to enter into contracts. ${ }^{51}$ GR30 notes the consequent obligations on States to remedy violations caused by conflict and makes several recommendations to States parties to this end. ${ }^{52}$

While GR30 now constitutes an authoritative statement of women's human rights in conflict, there are clear limitations to the Committee's traction over, firstly and most clearly, UN member States that have declined to ratify the Convention. ${ }^{53}$ Such States are small in number, yet they include some significant actors in armed conflict and women's rights - most notably the United States, but also Iran and Somalia. The CEDAW Committee's oversight procedures have no bearing on these States and their conduct of hostilities domestically or internationally. The structural weaknesses historically associated with the Convention, due to the lack of any associated enforcement procedures, have been ameliorated in important ways through the entry into force of the Optional Protocol to the Convention in December 2000 , which established an individual communications mechanism ${ }^{54}$ and an inquiry procedure to investigate 'grave or systematic violations' of the Convention. ${ }^{55}$ Nevertheless, these enhanced monitoring procedures are likewise limited to State parties to the Optional Protocol, which remains well behind the number of State parties to the Convention. ${ }^{56}$

41 Committee for the Elimination of All Forms of Discrimination against Women, 'General Recommendation No. 28' (19 October 2010) UN Doc CEDAW/C/GC/28 para 11; CEDAW (n 2) para 2; Committee for the Elimination of All Forms of Discrimination against Women, 'Concluding Observations to Israel' (22 July 2005) UN Doc CEDAW/C/ISR/3 paras 23-24; see also Committee for the Elimination of All Forms of Discrimination against Women, 'Statement on the Situation of Women in Gaza' (18 July 2014) Decision 58/1, UN Doc CEDAW/C/2014/II/ CRP.

42 P Patten statement to 'Arria Formula Meeting on Linkages between Security Council on Resolution 1325 and CEDAW GR 30' (5 December 2016) United Nations.

43 CEDAW (n 2) paras 10, 34-37, 53-56, 58-60.

45 ibid paras 39-40. $\quad 46$ ibid paras 42-46, 70-72. $\quad 47$ ibid paras 48-51. 48 ibid.

49 ibid paras 58-60. $\quad 50$ ibid paras 62-64. $\quad{ }_{51}$ ibid paras 74-80.

52 ibid paras $12,17,24,28,33,38,41,46,52,57,61,65,69,73,81,82-86$.

53 At the time of writing, there are 189 State parties to the Convention. $\quad 54$ Art 2.

55 Art $8 . \quad 56$ At the time of writing, there are 107 State parties to the instrument. 
The accountability activities of the Committee encounter further grave restrictions imposed by widespread reservations to the Convention. ${ }^{57}$ The Convention bears the unfortunate distinction of being the human rights treaty subject to the largest number of reservations by ratifying States. According to Charlesworth and Chinkin, 'some states have used the reservation mechanism effectively to hollow out the heart of their formal obligations' ${ }^{58}$ These widespread reservations likewise erode the Committee's capacity to effectively monitor and enforce the Convention's protections of women's rights in conflict against all State parties. An additional obstacle to the activities of the Committee in respect of State parties and their protection of women's rights in conflict is the 'soft law' status of GR30. While general recommendations form an important element of the Committee's normative and interpretative role, they only have persuasive status under international law and, as such, face resistance to their strict application by some State parties. 59

Beyond the challenge of non-ratifying UN member States, or 'insincere' State parties, ${ }^{60}$ the Convention is also limited by its strict application to States only. While States are the central actors of any regime of international law, the practice of international peace and security proceeds largely through organs and actors that do not constitute member States in a strict sense. The multilateral activities of the United Nations derive their legal authority from the consent of all member States to the UN Charter. In practical terms, many of the UN's activities on women's rights in conflict take place through dedicated UN programmes and agencies, operating globally and, in some instances, at country level. The CEDAW Committee is thus able to establish a measure of accountability over some UN programmatic activity in countries under periodic examination. (In practice, the Committee has used its monitoring procedures not only in relation to State parties but also, as appropriate, in relation to UN specialized agencies and UN country teams. ${ }^{61}$ Nevertheless, such monitoring is partial, not public and is dependent on tradition and

\footnotetext{
57 See generally R Cook, 'Reservations to the Convention on the Elimination of All Forms of Discrimination of Women' (1990) 30 VaJIntlL 643.

${ }^{58} \mathrm{H}$ Charlesworth and C Chinkin, The Boundaries of International Law: A Feminist Analysis (Manchester University Press 2000) 113.

59 There is an extensive literature addressing the legal status of so-called 'soft law', such as general recommendations. For a feminist scholarly treatment of this debate, see for example C Chinkin, 'The Challenge of Soft Law: Development and Change in International Law' (1989) 38 ICLQ 850; H Charlesworth, 'Law-making and Sources' in J Crawford and M Koskenniemi (eds), The Cambridge Companion to International Law (Cambridge University Press 2012) 187-202.

${ }^{60}$ B Simmons, Mobilizing for Human Rights: International Law in Domestic Politics (Cambridge University Press 2009) 77.

61 While these reports are confidential, their outline contents are set out in UNICEF, CEDAW and the Reporting Process to the Committee on the Elimination of Discrimination Against Women: A Guide for UNICEF Field Staff(Division of Policy and Practice, March 2009) Annex 9: Guidelines for UN Country Team reports to the CEDAW Committee, 104.
} 
goodwill, rather than strict legal obligation. ${ }^{62}$ Broader UN programmatic activity on peace and security, such as the work of the Peacebuilding Commission, and political decision-making, such as by the UNSC or General Assembly, is effectively shielded from CEDAW Committee's system of State accountability. While the Committee has interpreted the Convention to include obligations on State parties in their multilateral activities on peace and security, ${ }^{63}$ such an approach cannot provide adequate capture of intergovernmental political and programmatic activities on women's rights in conflict. Given the importance of activity and decision-making at intergovernmental level to the treatment of women's rights in conflict, this is not an inconsequential gap.

\section{B. The UNSC and Women's Rights in Conflict}

Typically regarded as the UN organ that is most militaristic and driven by global power politics, the UNSC is not formally attributed a role in advancing human rights by the UN Charter. ${ }^{64}$ Rather, the UNSC has the responsibility to weigh the evidence in individual circumstances and to identify threats to the peace, breaches of the peace, and acts of aggression. ${ }^{65}$ In determining the appropriate response to situations on its agenda, the UNSC can choose between its recommendatory powers under Chapter VI for the 'Pacific Settlement of Disputes' or its binding powers under Chapter VII for 'Action with Respect to Threats to the Peace, Breaches of the Peace, and Acts of Aggression'. Envisaged as the enforcement body of the United Nations, the UNSC has unique authority to make binding decisions ${ }^{66}$ and extraordinary powers that include the authorization of the use of force. ${ }^{67}$ Those extraordinary powers reflect the primary mandate of the organ, namely 'the maintenance of international peace and security'. ${ }^{68}$

The UN Charter's preambular and Article 1 commitments to 'promote and encourage respect for human rights' imply a role for all UN organs. Moreover, human rights violations of sufficient severity can themselves constitute threats to international peace and security. ${ }^{69}$ These Charter

62 It is addressed in GR30 (n 2) paras 84-85.

63 ibid para 82.

${ }^{64}$ Charter of the UN (n 27) Ch V.

65 ibid art 39. See generally ibid Chapter VII, Action with Respect to Threats to the Peace, Breaches of the Peace, and Acts of Aggression. $\quad 66$ ibid art $25 . \quad 67$ ibid.

68 ibid art 24(1).

69 For example, in UNSC Res 1366 (2001) OP 10, the Security Council invited the SecretaryGeneral:

$[\mathrm{T}] \mathrm{o}$ refer to the Council information and analyses from within the United Nations system on cases of serious violations of international law, including international humanitarian law and human rights law and on potential conflict situations arising, inter alia, from ethnic, religious and territorial disputes, poverty and lack of development and expresses its determination to give serious consideration to such information and analyses regarding situations which it deems to represent a threat to international peace and security. 
provisions have been the subject of highly varying interpretation by the UNSC during the seven decades of its operation. ${ }^{70}$ While 'the UNSC was not intended as a forum to debate and devise solutions to human rights issues', ${ }^{71}$ it first acknowledged that the systematic violation of rights could constitute an issue of international peace and security in the 1960s. ${ }^{72}$ A growing, if indirect, role on human rights relevant to its mandate began to develop in the 1990s. ${ }^{73}$ The end of the Cold War brought a new era of human rights across the wider UN system, ${ }^{74}$ and with it increasing scrutiny of the UNSC and its legitimacy, including calls for the UNSC to reform, to democratize and to address the impact on human rights of its own operations. ${ }^{75}$ These calls for reform overlapped with a feminist spotlight on rights violations impacting women in conflicts such as the former Yugoslavia and Rwanda, and calls for a refocus by the UNSC on the people affected by conflict and by its operations. ${ }^{76}$

Developments in the UN more broadly in the 1990s also had an important impact on the UNSC agenda. The UN Development Programme's 1994 Human Development Report introduced the concept of 'human security' to the UN, which relocated the idea of global security, formerly situated in arms and State-centric concerns, to that located in all aspects of human development. ${ }^{77}$ While the concept of human security has experienced varying degrees of legitimacy itself since, and its conceptual emergence may be critiqued for the omission of gender or feminist concerns, ${ }^{78}$ it nevertheless provided an entry point for feminist activism and for the increasing adoption of thematic resolutions by the UNSC (a clear avenue through which it makes the connection with broader human rights-related issues). ${ }^{79}$

70 See generally SD Bailey, The UN Security Council and Human Rights (St Martin's Press 1994); JG and BS Ugarte, The UN Security Council in the Age of Human Rights (Cambridge University Press 2014).

71 A-G Tachou-Sipowo, 'The Security Council on Women in War: Between Peacebuilding and Humanitarian Protection' (2010) 92 International Review of the Red Cross 197, 198.

72 BS Ugarte and J Genser, 'Evolution of the Security Council's Engagement on Human Rights' in BS Ugarte and J Genser (eds), The United Nations Security Council in the Age of Human Rights (Cambridge University Press 2014) 5.

73 ibid 5-6.

74 See generally J Mertus, The United Nations and Human Rights: A Guide for a New Era (2nd edn, Routledge 2009).

75 D Otto, "Securing the "Gender Legitimacy" of the UN Security Council: Prising Gender from its Historical Moorings' in H Charlesworth and JM Coicaud (eds), Fault Lines of International Legitimacy (United Nations University Press 2006).

76 ibid.

77 United Nations Development Programme, Human Development Report 1994 (Oxford University Press 1994); J Dedring, 'Human Security and the UN Security Council' in HG Brauch et al. (eds), Globalisation and Environmental Challenges: Reconceptualising Security in the 21st Century (Springer 2008).

78 C Ryerson, 'Critical Voices and Human Security: To Endure, To Engage or to Critique' (2010) 12 Security Dialogue 169.

79 C True-Frost has documented that between January 1999 and October 2007, the UNSC adopted 41 thematic-focused resolutions. Prior to this, from the creation of the Council in 1946 to the adoption of human security concepts in 1999, it adopted only 13 thematic resolutions; C True-Frost, 'The Security Council and Norm Consumption' (2007) 40 International Law and Politics 115, 139-40. 
The UNSC made a first ambitious step towards embedding women's rights in conflict within its agenda by issuing a press release on 8 March 2000, on the occasion of International Women's Day, declaring that 'members of the UNSC recognize that peace is inextricably linked with equality between women and men' ${ }^{80}$ A series of further steps included an arria formula meeting, ${ }^{81}$ an open debate on women, peace and security and finally the adoption of Resolution 1325 in October 2000. ${ }^{82}$ The Resolution provides for four principal pillars of priority action in which women's rights should be advanced, namely: Participation, Protection, Prevention, and Relief and Recovery. The resolution is widely celebrated for its recognition of women's gender-specific experiences of conflict and of women as agents of conflict transformation. ${ }^{83}$

As the resolution drew attention for its symbolic importance, practical concerns about weak provision for implementation quickly emerged. ${ }^{84} \mathrm{In}$ response to such concerns, seven additional WPS resolutions were adopted. Three focus broadly on advancing the women's participation pillars (Resolution 1889 (2009), Resolution 2122 (2013), Resolution 2242 (2015) 85 ) and four focus on conflict-related sexual violence (CRSV) (Resolution 1820 (2008), Resolution 1888 (2009), Resolution 1960 (2010) and Resolution $\left.2106(2013)^{86}\right)$. These additional resolutions have extended the breadth and depth of Resolution 1325, made provision for the implementation of the overall WPS agenda and engaged a broad range of member States willing to lead adoption of additional resolutions on this issue.

While the WPS resolutions have signalled important political recognition by the UNSC that women's inequality and rights are concerns of peace and security, a number of critiques have emerged. Numerous feminist scholars and activists have pointed to shortcomings in how the UNSC has engaged with concepts of gender and with the discriminations that characterize women's lives. For example, a central motivation for activists in calling for the adoption of Resolution 1325 (2000) was to overcome the exclusion of women from decision-making, as well as increasing women's role in the general activities that fall within the remit of the UNSC. In 1993, 1 per cent of deployed peacekeeping personnel were women, which has barely increased to 3 per cent by $2014 .{ }^{87}$ Of 31 peace agreements signed between

${ }^{80}$ United Nations, 'Peace Inextricably Linked with Equality between Women and Men Says Security Council, in International Women's Day Statement' Press Release (8 March 2000) SC/6816.

${ }^{81}$ United Nations Secretariat, 'Background Note on the "Arria-Formula" Meetings of the Security Council Members’ Informal Non-Paper (25 October 2002), <http://www.un.org/en/sc/ about/methods/bgarriaformula.shtml $>$. $\quad{ }^{82}$ UNSC Res 1325 (2000) S/RES1325/2000.

${ }^{83}$ C Cohn, H Kinsella and S Gibbings, 'Women, Peace and Security' (2004) 6 International Feminist Journal of Politics 130.

85 UNSC Res 1889 (2009) S/RES1889/2009; UNSC Res 2122(2013) S/RES2122/2013; UNSC Res 2242 (2015) S/RES2242/2015.

${ }^{86}$ UNSC Res 1820 (2008) S/RES1820/2008; UNSC Res 1888 (2009) S/RES1888/2009; UNSC Res 1960 (2010) S/RES1960/2010; UNSC Res 2106 (2013) S/RES2106/2009.

87 United Nations, 'Women in Peacekeeping' (6 July 2017) <http://www.un.org/en/ peacekeeping/issues/women/womeninpk.shtml>. 
1992 and 2011, only 4 per cent of signatories, 2.4 per cent of chief mediators, 3.7 per cent of witnesses and 9 per cent of negotiators were women. ${ }^{88}$ While the resolutions call for the increased participation of women, they are absent of language that articulates measures to address the fundamental basis of women's exclusion, namely addressing structural inequalities and gender discrimination.

There are significant concerns that issues such as women's participation have been engaged with by the UNSC only in as far as they advance the UNSC's and States' security agendas. ${ }^{89}$ For example, the UNSC-mandated 2015 Global Study on the Implementation of Resolution 1325 documented concerns among women's activists globally that there are adverse consequences for women's security when States co-opt the work of women's organizations into State security strategies. ${ }^{90}$ In particular, with respect to the prevention of violent extremism, Resolution 2242 (2015) calls for the participation of women and women's organizations in the development of counterterrorism strategies. ${ }^{91}$ There are fears that the mantle of women's participation in national security will become a means for States to simply interpret participation as a role for women in intelligence gathering. ${ }^{92}$ Women activists have expressed concerns 'of women being "used" by the government, rather than being empowered to participate fully in society and overcome the barriers they face' ${ }^{93}$ In addition, where States fund women's rights activities as a means to counter radicalism, rather than for the purposes of promoting gender equality per se, the perception that these organizations are linked with State security strategies can compromise trust and safety within their communities. ${ }^{94}$

Compounding these complexities, contestation endures within the UNSC in respect of its role vis-à-vis thematic issues such as WPS, their tie to its specific mandate and how it engages with these issues relative to the wider human rights system. ${ }^{95}$ Fundamental concerns about the WPS agenda at the UNSC make the investigation of alternative and complementary means to advance women's rights in conflict, such as the CEDAW Committee, all the more urgent.

88 P Castillo Díaz and S Tordjman, 'Women's Participation in Peace Negotiations: Connections between Presence and Influence' in UN Women Sourcebook on Women, Peace and Security (UN Women 2012).

89 N Hudson, 'Securitizing Women's Rights and Gender Equality' (2009) 8 Journal of Human Rights 53.

${ }_{90}$ R Coomaraswamy, 'Preventing Conflict, Transforming Justice, Securing the Peace: A Global Study on the Implementation of UNSC Resolution 1325' (UN Women 2015) 222.

91 UNSC Res 2422 (2015) S/RES/2422, paras 11-13.

92 Organisation for Security and Cooperation in Europe, 'Women and Terrorist Radicalization: Final Report' (OSCE 2013) 5.

93 Coomaraswamy (n 90) 222.

94 N Chowdhury Fink, R Barakat and L Shetret, 'The Roles of Women in Terrorism, Conflict, and Violent Extremism: Lessons for the United Nations and International Actors' (Center on Global Counterterrorism Cooperation 2013) 6.

95 Security Council Report, 'Women, Peace and Security: Sexual Violence in Conflict and Sanctions' (10 April 2013) 41. 


\section{INSTITUTION-SPECIFIC ACTIVITY FOR ACCOUNTABILITY ON WOMEN'S RIGHTS IN CONFLICT}

\section{A. CEDAW Committee Activity on Women's Rights in Conflict}

The CEDAW Committee has been an advocate for women's rights in conflict since long before the adoption of either GR30 or the WPS resolutions at the UNSC. As this section outlines, despite the noted limitations of the Convention due to reservations and weak monitoring procedures, there are grounds for confidence in the Committee's capacity to pursue State accountability for women's rights in conflict. A review of the Committee's activities to ameliorate the impact of conflict on women's rights, and to ensure those rights are fulfilled through conflict and peacebuilding initiatives, evidences long-standing and considered engagement. Both in law and in practice, the Committee's mechanisms for State accountability continue to operate during conflict and civil unrest. The Committee has done this through the effective exercise of its four complementary roles, namely periodic State monitoring; 'monitoring-plus' activities such as issuing special 'statements' and requesting 'exceptional reports'; norm-development through advancing feminist-informed interpretation of both the Convention and broader human rights commitments; and enhanced monitoring activities through the Optional Protocol. These are reviewed here in turn, in addition to a consideration of how such Committee activities contribute to women's rights on the ground in conflict-affected States.

Most importantly, the Committee conducts the periodic review of State compliance with obligations under the Convention. For example, in its monitoring of periodic State reporting, the Committee has drawn attention to levels of women's representation in post-conflict democratic institutions ${ }^{96}$ and has likewise urged State parties to ensure the inclusion of women in ongoing peace processes within State parties' jurisdiction. ${ }^{97}$ Moreover, the Committee has drawn attention to the impact of conflict on substantive rights guaranteed under the Convention, such as the right of women and girls to education on a basis of non-discrimination..$^{98}$ Further, the Committee has

${ }^{96}$ Committee for the Elimination of All Forms of Discrimination against Women, 'Concluding Observations to Serbia' (11 June 2007) UN Doc CEDAW/C/SCG/CO/1; Committee for the Elimination of All Forms of Discrimination against Women, 'Concluding Observations to Rwanda' (12 February 2009) UN Doc CEDAW/C/RWA/CO/6.

${ }_{97}$ Committee for the Elimination of All Forms of Discrimination against Women, 'Concluding Observations to Israel' (3 August 2005) UN Doc CEDAW/C/ISR/CO/3, para 22; Committee for the Elimination of All Forms of Discrimination against Women, 'Concluding Observation to Cyprus' (13 June 2006) UN Doc CEDAW/C/CYP/CO/5, para 270.

${ }_{98}$ Committee for the Elimination of All Forms of Discrimination against Women, 'Concluding Observations to Sierra Leone' (11 June 2007) UN Doc CEDAW/C/SLE/CO/5, para 30; Committee for the Elimination of All Forms of Discrimination against Women, 'Concluding Observations to Colombia' (20 February 2007) UN Doc CEDAW/C/COL/CO/6, para 30; Committee for the Elimination of All Forms of Discrimination against Women, 'Concluding Observations to Liberia' (14 August 2009) UN Doc CEDAW/C/LBR/CO/6. 
enhanced these periodic reporting procedures through the activation of what might be termed 'monitoring-plus' activities. These have taken the form of 'statements' addressing particular women's human rights situations of concern. ${ }^{99}$ Of particular note is the Committee's utilization of its Article 18 (1)(b) authority to request State party reports on an 'exceptional' basis, in order to examine information on actual or potential violations where there is special cause for concern. ${ }^{100}$ Interestingly, these 'exceptional reports' have to date exclusively pertained to conflict-affected State parties, beginning with the Committee's 1995 request to countries in the former Yugoslavia to submit reports addressing acts of violence against women and girls, including mass rape and rape used as a weapon of war. ${ }^{101}$

Many commentators have underlined the role that the reporting procedure can play in furthering implementation of the Convention's norms. ${ }^{102}$ The process of reporting focuses governments' attention on the treaty obligations and requires them to evaluate progress. It also provides an opportunity for civil society to engage with government during the preparation of the report and the Committee's review, as well as in following up on the Committee's concluding observations. The reporting procedure provides an international forum where the government is on display globally and nationally, and provides the occasion for a UN-designated group of experts to make targeted substantive recommendations on steps that should be taken to advance women's equality. ${ }^{103}$ Thus, the CEDAW Committee's requests for 'exceptional reports' in cases of conflict have both symbolic and practical

99 For example, its Statement on Women in Gaza, Committee for the Elimination of All Forms of Discrimination against Women, 'Statement on the situation in Gaza', (6 February 2009) UN Doc A/64/38 (supp) Annex II, and Statement on Inclusion of Afghan Women in Peace Building, Committee for the Elimination of All Forms of Discrimination against Women, 'Statement on the Inclusion of Afghan Women in the Process of Peace Building', Security and Reconstruction in Afghanistan, 45th Session (January 2010) UN Doc/E/CN6/2010/CRP 2 Annex V 199.

100 See further Freeman et al. (n 34) 500.

101 The Committee has requested and received five reports on an exceptional basis: from the then Federal Republic of Yugoslavia, Croatia, Bosnia, Rwanda and the Democratic Republic of the Congo (Committee for the Elimination of all Forms of Discrimination against Women, 'Concluding Observations to Croatia' (1995) UN Doc A/50/38, paras 585-586; Committee for the Elimination of all Forms of Discrimination against Women, 'Concluding Observations to Bosnia and Herzegovina' (1994) UN Doc A/49/38, para 736; and repeated this scrutiny on Bosnia in the 2006, paras 37-38 examination) Bosnia and Herzegovina 1 February 1994 (oral report; see CEDAW/C/SR.253) Thirteenth (1994); Democratic Republic of the Congo 16 January 1997 (oral report; see CEDAW/C/SR.317) Sixteenth (1997); Croatia, 6 December 1994 (CEDAW/C/CRO/SP.1) Fourteenth (1995); Rwanda 31 January 1996 (oral report; see CEDAW/ C/SR.306) Fifteenth (1996); Federal Republic of Yugoslavia (Serbia and Montenegro) 2 December 1993 (CEDAW/C/YUG/SP 12 February 1994 (oral report; see CEDAW/C/SR.254) Thirteenth (1994). In 2009, India was asked to report on an exceptional basis on the impact on women of violence in Gujarat (2009) although ultimately incorporated the requested content in its scheduled periodic report of 2010, Committee for the Elimination of all Forms of Discrimination Against Women, 'Concluding Observations' to India (2 Nov 2010) UN Doc $\mathrm{CEDAW} / \mathrm{C} / \mathrm{IND} / \mathrm{CO} / \mathrm{SP}$, paras 2-4.

102 For example, A Byrnes and MA Freeman, 'The Impact of the CEDAW Convention: Paths to Equality, A Study for the World Bank’ (World Bank 2011).

103 ibid 12. 
significance. In symbolic terms, the request highlights international awareness and concern with the gender-specific impact of conflict on women's rights in particular conflict settings. In practical terms, the request requires State parties to gather further information, data and evidence concerning the gender-specific impact of conflict, which can in turn usefully support local women's movements in seeking amelioration and redress for the most exigent effects of conflict on women. ${ }^{104}$

Critically, the CEDAW Committee plays a unique role in advancing feminist-informed interpretations of the treaty's provisions and, ultimately, in shaping normative development of international human rights law. The Committee undertakes this work in particular by articulating authoritative interpretations of the Convention through its General Recommendations, which have demonstrated growing attention to the specific impact of conflict on the enjoyment of rights guaranteed under the Convention. With General Recommendation Number 19 (GR19) on violence against women, the Committee advanced its first substantive discussion in a general recommendation of the impact of conflict on the enjoyment of rights guaranteed under the Convention. ${ }^{105}$ Further, General Recommendation Number 28 (GR28) on the nature of the Convention's obligations on State parties marked the Committee's clearest statement hitherto that the Convention also applies in its entirety to situations of armed conflict. ${ }^{106}$ This trajectory culminated in the adoption of GR30 on women's rights in conflict. Experience from the campaign to recognize violence against women as a human rights violation evidences the importance of the CEDAW Committee in articulating and advancing subaltern interpretations of human rights obligations that ultimately penetrate the mainstream human rights system. ${ }^{107}$ As Merry observes: 'Culture is as much present in international human rights conferences and UN institutions as in local villages (though typically associated only with the latter).' ${ }^{108}$ Normative developments led by the CEDAW Committee have been shown to foster broader cultural change within the international human rights system. ${ }^{109}$

The structural weaknesses historically associated with the Convention, due to the lack of enhanced monitoring procedures permitting the Committee to

\footnotetext{
104 See further text at (nn 114-118).

106 GR30 (n 2) para 11.

107 A Edwards, Violence against Women under International Human Rights Law (Cambridge University Press 2011) 168-72.

108 SE Merry, Human Rights and Gender Violence: Translating International Law into Local Justice (University of Chicago Press 2006) 16.

109 See, for example, the Report of the Secretary-General, 'In-depth Study on All Forms of Violence against Women’ (2006) UN Doc A/61/122/Add.1, 13 para 31, noting that:
}

The work of the Committee on the Elimination of Discrimination against Women, the treaty body established in 1982 to monitor implementation of the Convention on the Elimination of All Forms of Discrimination against Women, contributed significantly to the recognition of violence against women as a human rights issue. 
determine violations in specific incidences, have been ameliorated in important ways through the entry into force of the Optional Protocol to the Convention in December 2000. Enhanced monitoring activities for conflict-related violations have, to date, been limited. The Committee has, however, been consistent in rejecting any claim by States that issues of asylum are not addressed by the Convention. ${ }^{110}$ In the case of individual petitions emerging from conflictaffected settings, where domestic legal systems are likely to be debilitated and the ability to gather evidence hampered, future jurisprudence will be important in illuminating whether more flexible standards are applied to evidential requirements and procedural requirements concerning the exhaustion of domestic remedies. Likewise, the Committee has not yet activated the Optional Protocol's inquiry procedure in order to investigate 'grave or systematic violations' of the Convention specifically due to conflict. Nevertheless, the clearest strand of activity by the Committee in the jurisprudence emerging from the Optional Protocol is violence against women. ${ }^{111}$ The consistent line of the Committee's inquiry activity has been to investigate and hold State parties to account for violence against women by non-State actors. ${ }^{112}$ This latter feature, in particular, of the Committee's enhanced monitoring activities has considerable relevance for its likely approach to 'grave or systematic violations' occurring in conflict-affected settings.

It is clear therefore that the CEDAW Committee has utilized its powers to draw attention to the impact of conflict on women's rights. The ways in which the Committee's activities translate into improved protection of women's rights on the ground has been given extensive academic consideration. Indeed, in their comparative study of the relative efficacy of human rights treaties, Englehart and Miller concluded that the Convention was even more effective than its counterparts in achieving a statistically significant and positive effect on human rights, what they termed 'the CEDAW effect'. ${ }^{113}$ The most consistent finding across this scholarship is that the CEDAW Committee's activities are effective domestically where they connect with local reform constituencies, in particular women's civil society. ${ }^{114}$ In the most wide-reaching and academically significant of such studies, Beth Simmons concludes that human rights treaties' impacts lie less in their direct relationship with State parties, but rather in the mobilizing

\footnotetext{
110 Y.W. v Denmark, Comm No 51/2013, UN Doc CEDAW/C/60/D/51/2013 (2015); S.O. v Canada, Comm No 49/2013, UN Doc CEDAW/C/59/D/49/2013 (2014).

111 See further A Byrnes and E Bath, 'Violence Against Women, the Obligation of Due Diligence, and the Optional Protocol to the Convention on the Elimination of All Forms of Discrimination Against Women-Recent Developments' (2008) 8 HRLRev $517 . \quad 112$ ibid.

113 NA Englehart and MK Miller, 'The CEDAW Effect: International Law's Impact on Women's Rights' (2014) 13 Journal of Human Rights 22.

114 Byrnes and Freeman (n 102) 51; M McPhedran, S Bazilli, M Erickson and A Byrnes, The First CEDAW Impact Study: Final Report (Centre for Feminist Research, York University, Toronto and International Women's Rights Project 2000); Simmons (n 60).
} 
framework that they offer to domestic reform constituencies. ${ }^{115}$ Thus, NGO use of shadow and communication reporting procedures, and further utilization of Concluding Observations and General Recommendations, has been found to be critical to the Committee's efficacy on the ground. ${ }^{116}$ Importantly, these conclusions were drawn from studies involving both conflict-affected and non-conflict States. One illustrative example concerns the CEDAW Committee's repeated criticism of the UK's failure to include Northern Ireland within its National Action Plan on Women, Peace and Security. ${ }^{117}$ This consistent attention by the Committee has proven important in supporting and sustaining local women's advocacy for an improved and better-coordinated State response to the impact of the conflict and its legacy on women's rights. ${ }^{118}$

\section{B. UNSC Activity on Women, Peace and Security}

The activity and productivity of the UNSC on WPS should be measured not only by its prolific adoption of resolutions as outlined, but also by its growing and consistent engagement with this agenda through its procedural workings. The UNSC has held an annual open debate on WPS since 2002 (with a Presidential Statement delivered since 2001). From 2009, this became two WPS open debates per year; one on the WPS agenda broadly and one focused on its resolutions on conflict-related sexual violence (CRSV). ${ }^{119}$ As requested through the WPS resolutions, the Secretary-General presents one annual report to the UNSC on WPS broadly. Since 2009, the Secretary Security-General has presented an additional report on CRSV. ${ }^{120}$ Hosting, attending and advancing a body of work required by two debates and two reports per year represents a significant resource and time commitment on the part of the UNSC to this agenda item, as well as a significant resource commitment from the UN system entities that fulfil these requests. While two UNSC members are 'penholders' for the agenda (UK for WPS broadly, US for CRSV), and to some degree drive this continuing engagement, the level of

115 Simmons (n 60) 253-4.

116 McPhedran et al. (n 114) 18.

117 Committee on the Elimination of All Forms of Discrimination Against Women, 'Summary Record (Partial) of the 1143rd Meeting, Consideration of Reports Submitted by States Parties under Article 18 of the Convention (Continued) Seventh Periodic Report of the United Kingdom of Great Britain and Northern Ireland (Continued)' (2013) UN Doc CEDAW/C/SR.1143, paras 14 and 26; Committee on the Elimination of All Forms of Discrimination Against Women, 'Summary Record (Partial) of the 844th Meeting, Consideration of Reports Submitted by States Parties under Article 18 of the Convention (Continued) Fifth and Sixth Periodic Reports of the United Kingdom of Great Britain and Northern Ireland (Continued)' (2008) UN Doc CEDAW/C/SR.844, paras 4 and 15.

118 For a full account of these dynamics, see O'Rourke (n 7).

119 For an overview, see A Swaine, 'Substantive New Normative Provisions on Women and Armed Conflict Concurrently Adopted by the UNSC and the CEDAW Committee' (2014) 18 ASIL Insights 5.

120 See, for example, UNSC, 'Report of the Secretary-General on Conflict-Related Sexual Violence' (22 June 2016) UN Doc S/2016/361/Rev.1. 
activity has largely been driven by and involved a broad constituency of transnational civil society networks and UN entities such as UN Women. ${ }^{121}$ This activity across the UNSC, UN entities and civil society has generated a new locus and modality for issues of women and conflict that has not been seen before in respect of the UN system. It has proven remarkably productive of a whole new realm of activity dedicated exclusively to the implementation of the UNSC's WPS agenda at international, regional and local levels, ${ }^{122}$ quite apart from the UN organs formally mandated to pursue such issues under the Charter.

While these developments evidence remarkable progress both normatively and procedurally, there remain pronounced concerns regarding the lack of meaningful accountability mechanisms for the implementation of the resolutions. Further, a number of critical tensions arise from engaging a body such as the UNSC to advance women's rights in ways akin to that of the human rights regime. Ultimately, the politics of the UNSC's mandate and its operative modalities determine limitations that give rise to practical deficits in accountability in a number of ways. The UNSC mandate also, however, offers a number of unique opportunities that could be more fully maximized. Both the limitations and opportunities are summarized here.

In respect of limitations, first, it is important to recognize that the UNSC does not act as a monitoring body on State-level implementation of its resolutions or thematic issues. It is mandated to respond to threats to international peace and security and is not a legislative-like body. ${ }^{123}$ Rather, its resolutions are intended to be directed to specific member States with time-bound activities in order to redress particular threats. ${ }^{124}$ Other than the sui generis activities of the CounterTerrorism Committee, the UNSC lacks a mandate, function and means for holding member States accountable to its broad thematic resolutions. The UNSC instead requests that the UN Secretary-General update the UNSC on implementation of the WPS resolutions through the aforementioned thematic annual reports. ${ }^{125}$ It is important to note that, while these reports are compiled on the basis of information provided by member States on implementation of the resolutions, State submissions to the reporting process are to the UN Secretary-General (not the UNSC) and cooperation with reporting is not mandatory for States. The reports are important informative outputs and offer significant observations on progress towards implementation. They are not, however, a modality through which member States are directly accounting to the UNSC for implementation of the resolutions.

121 This is notably led by the 'NGO Working Group on Women, Peace and Security' that was formed in 2000 to lobby for the adoption of resolution 1325 and continues to advocate for implementation of the agenda, <http://www.womenpeacesecurity.org>.

122 Otto (n 75) on how 'productive' the entry to the Security Council has been.

123 Szasz (n 21).

125 UNSC Res 1325 (2000) S/RES1325/2000, paras 16-17. 
Secondly, the UNSC has not made full use of the accountability options available to it for its WPS agenda. The UNSC has the means to establish modes of accountability through its own working methods, such as through the establishment of committees and working groups to implement its thematic resolutions. To date, the UNSC has not shown any appetite for pursuing the option of creating a specific body, such as a working group, to advance accountability by member States for the WPS agenda. This gap further illuminates the accountability deficits attendant to this agenda item. By contrast with the WPS agenda, the UNSC established the Children and Armed Conflict working group in 2005, through its thematic agenda item on children. ${ }^{126}$ The working group monitors country contexts and makes recommendations for actions to be taken by States, non-State actors, the UN system and other actors. ${ }^{127}$

Thirdly, as the UNSC has failed to nominate mandatory measures for accountability for member State actions, civil society actors have instead been to the forefront of proposing modes of accountability. Principal among these civil society activities has been the call for UN member States to adopt State-level National Action Plans (NAPs) on WPS to implement the resolutions through national policy. ${ }^{128}$ While the adoption of NAPs by member States has been encouraged by the Secretary-General since 2002, and occasionally by Presidents of the UNSC, ${ }^{129}$ the UNSC itself has been slow to respond. Action plans were only formally recognized by the UNSC in an operational paragraph of Resolution 2242 (2015). However, the resolution only 'welcomes' the adoption of NAPs to date and 'encourages' further implementation strategies at national levels. ${ }^{130}$ Such language is to be distinguished from clear language of obligation. ${ }^{131}$ While this encouragement can be considered progress, these moves do not require or mandate States to adopt action plans, nor will their quality, efficacy and implementation be monitored in any formal way. States, such as Russia, also contest the idea that action plans are a universal accountability tool and instead posit that they should only be developed by States on the agenda of the UNSC to which the resolutions, in their view, are relevant. ${ }^{132}$ To a variable degree, however, member States have responded to calls for NAPs. As of the end of 2016, 63

\footnotetext{
126 UNSC Res 1612 (2005) S/RES1612/2005.

127 See UNSC Subsidiary Organs Working Group on Children and Armed Conflict, <https:// www.un.org/sc/suborg/en/subsidiary/wgcaac>.

${ }^{128}$ For a full discussion, see A Swaine, 'Assessing the Potential of National Action Plans to Advance Implementation of UNSC Resolution 1325' (2009) 12 YrbkIntlHumL 403-33.

129 UNSC, Statement of the President of the UNSC S/PRST/2002/32 (New York 2002); UNSC, Statement of the President of the UNSC S/PRST/2004/40 (New York 2004); United Nations, Report of the Secretary-General on Women, Peace and Security S/2002/1154 (New York 16 October 2002).

130 UNSC Res 2242 (2015) S/RES2242/2015, para 2.

131 See generally O’Rourke (n 7).

132 For example, Russia has stated: 'Our position continues to be that national plans of action on the implementation of resolution 1325 (2000) cannot be used as an instrument to assess national policies aimed at enhancing the status of women. Such plans should be drawn up on a voluntary
} 
States had adopted action plans on WPS. ${ }^{133}$ Civil society actors have filled in the gaps left by the UNSC's lukewarm engagement by supporting States to develop action plans. They - and scholars - have critiqued the quality and efficacy of NAPs, ${ }^{134}$ advocated for the application of the resolutions within both domestic and foreign policy ${ }^{135}$ and fulfilled a shadow role in monitoring the content and efficacy of these plans. ${ }^{136}$

Fourthly, the UNSC's primary response to criticism of the lack of enforcement measures within Resolution 1325 (2000) has been to adopt subsequent WPS resolutions. The response has therefore tended to replicate, rather than resolve, the broader enforcement and accountability deficits that characterize resolution 1325. Moreover, the subsequent resolutions set out modalities that are primarily directed towards the UN system rather than member States. To illustrate, Resolution 1889 (2009) provided provisions for implementation of Resolution 1325 (2000), which included a request to the Secretary-General to develop a set of global indicators to track the implementation of the resolution. It was intended that both member States and UN entities would voluntarily report against the indicators through the aforementioned UN Secretary-General's annual reports (with the majority of indicators aimed at the UN system). ${ }^{137}$ Although the indicators were presented by the Secretary-General to the UNSC in 2010, some members of the UNSC have contested their relevance and declined requests to report against them. As such, the application of the indicators has been far from universal, with UN agencies engaging with them much more than States. ${ }^{138}$ Resolution 1889 also proposed a strategy to increase the number of women in the UN system and to appoint gender and women's protection advisers within UN operations. ${ }^{139}$ Building on these provisions, Resolution 2122 (2013) strengthened approaches to women's participation and leadership throughout conflict prevention, peace processes and post-conflict reconstruction, and included requests for more frequent briefings on WPS to the UNSC by UN entities. ${ }^{140}$ Further, Resolution 2422 (2015) addressed UN activities on countering violent extremism and terrorism and committed to integrating WPS concerns across all country-specific situations on its

basis by those States that are in the grip of armed conflict or at the post-conflict reconstruction phase.' UN Security Council Meeting Record S/PV.7044 (18 October 2013).

133 To see a list of these action plans, see <http://www.peacewomen.org/member-states $>$.

134 See further Swaine (n 128). 135 ibid.

136 See the work of the Global Network of Women Peacebuilders, which runs a project titled 'Civil Society in Country and Global Monitoring of Security Council Resolution 1325' and publishes monitoring reports on multiple contexts globally, $<$ http://gnwp.peacegeeks.org/content/ civil-society-country-and-global-monitoring-unscr-1325>.

137 Security Council Report, 'Women, Peace and Security, Cross-Cutting Report No. 1' (27 January 2012) 41. $\quad 138$ ibid 11. $\quad 139$ UNSC Res 1889 (2009) S/RES1889/2009, para 7.

140 UNSC Res 2122 (2013) S/RES2122/2013, para 2. 
agenda. ${ }^{141}$ Despite this activity, grave concerns about implementation persist, in particular in the current accountability vacuum. ${ }^{142}$

In tandem with its limitations, there are opportunities that the UNSC's mandate offers in respect of unique entry points for the progression of women's rights in conflict. Engagement by the UNSC on the issue of CRSV has been accompanied by more robust implementation measures that also focus on the UN system-as distinct from member States-activities. Resolution 1820 (2008), which formally introduced CRSV as a defining WPS issue, was quickly followed by Resolution 1888 (2009) which established mechanisms for the earlier resolution's implementation and enforcement. Mechanisms included the appointment of a Special Representative of the Secretary General to advance the UN's work on addressing CRSV. ${ }^{143}$ Importantly, the next CRSV resolution, Resolution 1960 (2010), proposed a suite of mechanisms to advance accountability on this issue. These mechanisms included the establishment of a monitoring, analysis and reporting framework (MARA) that documents and tracks patterns of sexual violence. ${ }^{144}$ This has effectively enabled the Secretary-General to submit to the UNSC a list of actors-primarily non-State actors-involved in sexual violence. Further, Resolution 2106 (2013) includes provisions for securing prosecutions for CRSV, which does address both State and non-State actors. ${ }^{145}$

Of further significance is the UNSC's power to impose sanctions, a distinct strength of the UNSC. While the General Assembly holds broad powers to make recommendations for actions relating to peace and security, ${ }^{146}$ it concedes authority on measures of enforcement on these matters to the UNSC. ${ }^{147}$ In this capacity, the UNSC has come to include human rights abuses in its sanctions criteria, with evidence of a growing relationship between the sanctions system and the UNSC's own human rights-related actors. ${ }^{148}$ The link between the WPS agenda and the sanctions committee was first made in resolution 1820 (2008) and reiterated in Resolutions 1888 (2009), 1960 (2010), 2106 (2013) and 2242 (2015). ${ }^{149}$ The UNSC created a formal role for the Special Representative of the Secretary-General on Sexual Violence in Conflict who now regularly briefs the sanctions committee. The

141 UNSC Res 2422 (2015) S/RES2422/2015, para 11.

142 Coomaraswamy (n 90).

143 UNSC Res 1888 (2009) S/RES1888/2009, para 24.

144 UNSC Res 1960 (2010) S/RES1960/2010, paras 6, 8.

145 UNSC Res 2106 (2013) S/RES2106/2013, paras 2, 15.

146 UN Charter (n 27) arts 10, 11 and 12.

147 U Beyerlin, 'The United Nations Sanctions Regime' in R Wolfrum and C Philipp (eds), United Nations: Law, Policies and Practice, Vol 2 (Martinus Nijhoff Publishers 1995) 1113.

148 UNGA and UNSC, 'Compendium of the High-Level Review of the United Nations Sanctions' UN Doc A/69/941-S/2015/432 (New York 2015) 46.

${ }^{149}$ For full discussion, see Security Council Report (n 137). 
mandate of the Special Representative extends to naming and proposing individuals or entities to be sanctioned by the UNSC. ${ }^{150}$

To date, the UNSC has included sexual violence as a criterion in over half of its sanctions regimes. ${ }^{151}$ Sanctions regimes are only invoked, however, where there is a distinct threat to the peace and where other measures have failed. It is thereby distinctly and solely tied to the UNSC's definition of 'sexual violence, when used or commissioned as a tactic of war', and to the small number of country situations on the agenda of the UNSC. ${ }^{152}$ While this offers significant progress in respect to enforcement of standards of protection of women's rights, the potential to use sanctions to enforce decisions of the UNSC regarding WPS are thereby restricted to incidents that reach a certain threshold and that are within the agenda of the UNSC. There have been attempts, notably by the first Special Representative of the Secretary-General on Sexual Violence in Conflict through the Secretary-General's annual report, to expand coverage to wider forms of harm and ranges of contexts as relevant to the application of the UNSC resolutions. This attempt was met with rebuttal by some member States and the lines redrawn to those specific to the UNSC's agenda. ${ }^{153}$

Also significant in terms of unique opportunities offered by the UNSC is its distinctive role in making decisions on peacekeeping and political missions that are under its singular authority. The UN system's work has progressively shifted from the poverty focus of the 1990s to a security-driven agenda over which the UNSC has significant control. ${ }^{154}$ Currently, the UN's largest budget is attached to its security agenda and specifically to its peacekeeping operations. For fiscal year 2015-2016, these operations were budgeted at USD $\$ 8.27 \mathrm{bn} .{ }^{155}$ These are directly mandated by the UNSC. It is thereby the most significant body with the means to advance commitments to women's rights through these operations. Most recently, as the issue of sexual exploitation and abuse has arisen in these operations, the UNSC is the principal body with the power to establish provisions to prevent and respond to this issue (which it did in 2016). ${ }^{156}$ The UNSC can enforce legal requirements on women's rights through its missions by more stringent attention to, and accountability on, sexual exploitation and abuse.

${ }^{150}$ UNSC Res 1960 (2010) S/RES1960/2010, paras 3, 7, 8; UN Office of the Special Representative of the Secretary-General on Sexual Violence in Conflict, 'Provisional Guidance Note: Implementation of Security Council Resolution 1920 (2010) on Women, Peace and Security (Conflict-Related Sexual Violence)' (Stop Rape Now Campaign 2011) <http://www. refworld.org/docid/4e23ed5d2.html>. 151 ibid 71.

152 See, for example, UNSC Res 2262 (2016) on the situation in the Central African Republic S/ $\mathrm{RES} / 2262$

${ }^{153}$ See, for example, 'Statement by Russia' (17 April 2013) UN Security Council Meeting Record S/PV.6948. For broader analysis, see Security Council Report (n 95).

154 Coomaraswamy (n 90).

155 'Approved resources for peacekeeping operations for the period from 1 July 2015 to 30 June 2016, Note by the Secretary-General' (26 June 2015) UN Doc A/C.5/69/24.

156 UNSC Res 2272 (2016) S/RES/2272. 
The UNSC also has the power to adopt resolutions that stipulate actions and responses to specific country contexts. The need for State and non-State actors to prevent and address sexual violence in specific contexts has been included in resolutions as early as the 1990s, in response to events in the former Yugoslavia, and more recently in resolutions on contexts such as the Democratic Republic of the Congo. ${ }^{157}$ Referrals to the International Criminal Court (ICC) are within the UNSC's realm ${ }^{158}$ and, as such, referrals could potentially advance accountability for violations of women's rights in conflict. Neither of the first two such referrals explicitly included either reference to sexual or genderbased crimes. ${ }^{159}$ However, Resolution 1593 (2005) which referred Darfur to the ICC cites the report of the Darfur Commission of Inquiry. ${ }^{160}$ That report found that sexual violence took place as part of 'indiscriminate attacks ... conducted on a widespread and systematic basis' by government forces and militia. ${ }^{161}$ The ensuing investigation and warrants for arrest by the Prosecutor have included charges of rape, ${ }^{162}$ demonstrating the potential that such referrals from the UNSC may have in advancing accountability for violations of women's rights in conflict. This potential appears diminished, however, with the decreasing appetite of the UNSC for referrals to the ICC given the Kenya situation in 2013.163

While the WPS resolutions all prescribe a range of duties for UN member States, deeper scrutiny reveals that the accountability measures described are primarily focused on the UN system and entities and actors related to the UNSC (such as the Department of Peacekeeping Operations). There are few provisions that mandate member State action per se. The WPS resolutions have been accompanied by measures towards the collection of country-level data on specific elements of women's rights in conflict, yet an overall system of obligation and State accountability has, to date, not emerged. This failure

157 UNSC Res 2198 (2015) S/RES/2198.

158 Rome Statute, art 37(b).

159 The Council has referred the situation in Darfur, Sudan in 2005 and Libya in 2011 to the International Criminal Court, UNSC Res 1970 (2011) S/RES1970/2011; UNSC Res 1593 (2005) S/RES1593/2011.

${ }_{160}$ UNSC Res 1593 (2005) S/RES/1593, para 1.

161 Report of the International Commission of Inquiry on Darfur to the United Nations SecretaryGeneral Pursuant to Security Council Resolution 1564 of 18 September 2004 (25 January 2005).

162 See for example: Warrant of Arrest for Ahmed Harun, ICC-02/05-01/07 (27 April 2007); Warrant of Arrest for Ali Kushayb, ICC-02/05-01/07 (27 April 2007); Warrant of Arrest for Omar Hasasn Ahmad Al Bashir, ICC-02/05-01/09-1 (4 March 2009); Warrant of Arrest for Abdel Raheem Muhammad Hussein, ICC-02/05-01/12 (1 March 2012).

163 The prosecutor opened an investigation into the Kenya $2007 / 2008$ post-election violence in 2010. Calls for deferral of the case against the President and Deputy President were made by several African States following a terrorist attack in Nairobi in 2013 and in the run-up to elections in Kenya at that time. A resolution proposed by Rwanda, Morocco and Togo to defer the case was defeated in the Security Council, but served to escalate tensions over accusations that the ICC's focus on Africa represented colonial overreach on the continent, impacting appetite for further referrals for an interim period. Security Council Report, 'In Hindsight: The Council and the ICC' (30 May 2014) $<$ http://www.securitycouncilreport.org/monthly-forecast/2014-06/in_hindsight_the_council_ and_the_icc.php>. 
reflects both essential institutional aspects of the UNSC and broader deficiencies of political will. Where the WPS resolutions have offered greater promise in terms of accountability is in respect of relevant UN programmatic activity, sanctions, ICC referrals and peacekeeping.

IV. INTERACTIONS BETWEEN CEDAW AND THE UNSC ON WOMEN'S RIGHTS IN CONFLICT SETTINGS

\section{A. Thematic Interactions (and Boundaries) on Women's Rights in Conflict}

In comparing the thematic focus of activity between the CEDAW Committee and the UNSC, the significance of a structural understanding of gender and conflict becomes evident. While both institutions share some common thematic concerns - such as conflict prevention, gender-based violence and women's participation in peacebuilding - the Convention and GR30 go beyond the WPS resolutions in several critical respects. ${ }^{164}$ The WPS agenda, for example, does not address trafficking, nationality and statelessness, or marriage and family relations, yet these are specifically addressed in the Convention and GR30. ${ }^{165}$ Differences are not just evident in the themes addressed; they are perhaps even more pronounced in the approach adopted. In GR19, GR30 and throughout its activities, the CEDAW Committee has advanced an understanding of gender-based violence as both a cause and consequence of historically unequal relations between men and women. ${ }^{166}$ When addressing the specifics of conflict-related violence, therefore, the Committee understands and articulates the relationship of conflict-related violence to gender-based violence that precedes and survives the end of conflict. ${ }^{167}$ Moreover, the Committee situates such violence within the broader exacerbating effects of conflict on gender inequality and women's vulnerabilities to all forms of violence. ${ }^{168}$

This approach contrasts in dramatic and meaningful ways with the WPS resolutions' focus on 'sexual violence when used or commissioned as a tactic of war to deliberately target civilians or as part of a widespread or systematic attack against civilian populations'. ${ }^{169}$ Differences are further evident in approaches to perhaps the most fundamental gender issue in conflict: its prevention. Whereas the WPS resolutions advocate the increased participation of women in conflict prevention, ${ }^{170}$ the CEDAW Committee advocates conflict prevention per se in order to address the causes of conflict,

\footnotetext{
164 O'Rourke and Swaine (n 14) 19.

166 See generally Edwards (n 107); Freeman et al. (n 34) 444-74;

167 GR30 (n 3) paras 34-38.

169 UNSC Res 1820 (2008); 1888 (2009); 1960 (2010); 2106 (2013).

170 UNSC Res 1325 (2000) para 1; UNSC Res 1820 (2008) para 12; UNSC Res 2122 para 2(c).
} 
for example by calling on State parties to robustly regulate the arms trade and to appropriately control the circulation of conventional and small arms. ${ }^{171}$

Thematically, challenges remain in respect of moving the WPS agenda beyond instrumentalized and securitized approaches to women's inclusion, towards advancing the rights and equality end of this initial engagement in substantive ways. A relationship with the Convention, as the pivotal legal instrument on women's rights, does, however, provide a paradigm of nondiscrimination and substantive equality under which the WPS agenda could and should advance women's rights and accountability. This potential has been furthered through GR30. It has effectively brought the two systems of accountability and thematic activity on gender and conflict into conversation with one another and addressed the specifics of their relationships, thereby signalling the realignment of the WPS and broader international women's rights agendas. Whether and how their shared concern for thematic areas of interest, and for accountability on the same, is taken forward from this point will largely determine whether fragmentation across the regimes is entrenched, or the opportunity for enhanced synergy maximized, for common advancement of women's rights in conflict and peacebuilding. In light of the clear functional and thematic strengths of the CEDAW Committee and the UNSC's activities on women's rights in conflict, it is critical to consider how both institutions interact in the pursuit of maximum accountability and complementarity.

\section{B. Current Institutional Interactions between the CEDAW Committee and the UNSC}

In broad terms, it is clear that the CEDAW Committee is more open to productive interactions with the UNSC and its WPS agenda than vice versa. GR30 specifically addresses the relationship of the Convention to the WPS resolutions, substantively, in terms of the importance of implementing the resolutions in order to comply with State obligations under the Convention and, procedurally, in terms of the obligations on States to report on their WPS activities in their periodic reporting to the CEDAW Committee. ${ }^{172}$ GR30 further addresses the territorial application of the Convention - to State party activities within their borders, but also in bilateral relations with neighbouring States, in donor activities and foreign affairs, and in multilateral memberships of UN and regional organizations. ${ }^{173}$ As such, GR30 not only addresses States currently or recently in conflict, but rather addresses all State parties. It reflects a longer-term body of work by the Committee to bring domestic implementation of the resolutions under its purview and within the

\footnotetext{
171 GR30 (n 2) paras 29-38. GR30 also addresses gender-specific aspects of conflict-prevention, such as establishing early warning systems that include gender-related preventative actions and indicators.

172 GR30 (n 2).

173 GR30 (n 2) paras 8 and 9.
} 
Convention's formal mechanisms of State accountability. ${ }^{174}$ The substance of GR30, in particular through the express integration of the WPS resolutions and framework, has the evident potential to advance a new era of accountability for women's rights in conflict, while also ensuring that the WPS agenda remains firmly conceptualized within a broader women's rights and equality agenda.

Even prior to its adoption of GR30, the CEDAW Committee engaged in some monitoring of State party activity on Resolution 1325. In particular, the Committee has scrutinized State party adoption of National Action Plans (NAPs) on WPS. ${ }^{175}$ The Committee has fostered the adoption of NAPs by commending State parties that have done so, ${ }^{176}$ and encouraging other State parties to do likewise. ${ }^{177}$ Further, the Committee has scrutinized their content $^{178}$ and implementation. ${ }^{179}$ In addition to its scrutiny of NAP adoption, content and implementation, the Committee has also framed its recommendations to State parties on conflict-specific issues as constitutive of their implementation of Resolution 1325 (2000). ${ }^{180}$ It is noteworthy that the

174 For example, see Committee for the Elimination of All Forms of Discrimination against Women, 'Concluding Observations to the United Kingdom of Great Britain and Northern Ireland' (30 July 2013) UN Doc CEDAW/C/GBR/C07; and also Committee for the Elimination of All Forms of Discrimination against Women, 'Concluding Observations to the United Kingdom of Great Britain and Northern Ireland' (13 October 2009) UN Doc CEDAW/C/UK/ $\mathrm{CO} / 6$.

175 Swaine (n 128) 428, 432-3.

176 In 2006, the Committee commended Denmark for being one of the first States to adopt a NAP and in 2007 welcomed Norway's launch of a NAP. See Committee for the Elimination of All Forms of Discrimination against Women, 'Concluding Observations to Denmark' (24 August 2006) UN Doc CEDAW/C/DEN/CO6, para 6; and also Committee for the Elimination of All Forms of Discrimination against Women, 'Concluding Observations to Norway' (15 August 2007) UN Doc CEDAW/C/NOR/CO7, para 8.

177 In 2008, the Committee called on Myanmar to introduce a NAP, likewise Chad in 2011 and Afghanistan in 2013; Committee for the Elimination of All Forms of Discrimination against Women, 'Concluding Observations to Myanmar' (7 November 2008) UN Doc CEDAW/C/ $\mathrm{MMR} / \mathrm{CO} / 3$, para 25; Committee for the Elimination of All Forms of Discrimination against Women, 'Concluding Observations to Chad' (3 November 2011) UN Doc CEDAW/C/TCD/CO/ 1-4, para 29; Committee for the Elimination of All Forms of Discrimination against Women, 'Concluding Observations to Afghanistan' (30 July 2013) UN Doc CEDAW/C/AFG/CO/1-2, paras 8 and 9 .

178 In Côte d'Ivoire, the Committee noted with concern that the NAP did not reference CEDAW, Committee for the Elimination of All Forms of Discrimination against Women, 'Concluding Observation to Côte d'Ivoire' (8 November 2011) UN Doc CEDAW/C/CIV/CO/1-3, paras 14 and 15. In 2009 and 2013, the Committee raised concern with the UK that the NAP did not address Northern Ireland, Committee for the Elimination of All Forms of Discrimination against Women, 'Concluding Observation to the United Kingdom of Great Britain and Northern Ireland (13 October 2009) UN Doc CEDAW/C/UK/CO/6; Committee for the Elimination of All Forms of Discrimination Against Women, 'Concluding Observations to the United Kingdom of Great Britain and Northern Ireland (30 July 2013) UN Doc CEDAW/C/GBR/CO/7, paras 42 and 43.

179 Calling for improved implementation in Nepal, especially with regard to cases of sexual violence, Committee for the Elimination of All Forms of Discrimination against Women, 'Concluding Observation to Nepal' (11 August 2011) UN Doc CEDAW/C/NPL/CO/4-5, para 35.

${ }^{180}$ It urged Cyprus to ensure women's full participation in the peace process there, in line with 1325, Committee for the Elimination of All Forms of Discrimination against Women, 'Concluding Observations to Cyprus' (13 June 2006) UN Doc CEDAW/C/CYP/3-5, para 34. The Committee urged the Democratic Republic of the Congo to give specific attention to the post-conflict needs of women, in line with 1325, Committee for the Elimination of All Forms of Discrimination 
Committee's scrutiny of State party activity on WPS extends to both conflictaffected countries and donor countries.

GR30 responds both to concerns about the legal status and underenforcement of UNSC Resolution 1325 and to the fragmentation of international law norms for gender equality. ${ }^{181}$ GR30 is inter alia an effort to give retrospective legal status to the UNSC resolution 1325 and its successors. (Notably, GR30 characterizes the resolutions as "crucial political frameworks'. ${ }^{182}$ The recommendation characterizes implementation of the WPS resolutions as part of State party implementing obligations under the Convention, 'as all areas of concern addressed in those resolutions find expression in the substantive provisions of the Convention' ${ }^{183}$ In addition to retrospective legal status, the intervention by the Committee formally brings the domestic implementation of the resolutions into the purview of the monitoring role of the Committee:

States parties are to provide information on the implementation of the Security Council agenda on women, peace and security, in particular resolutions 1325 (2000), 1820 (2008), 1888 (2009), 1960 (2010) and 2106 (2013), including by specifically reporting on compliance with any agreed United Nations benchmarks or indicators developed as part of that agenda. ${ }^{184}$

Given timelines, there is a necessarily short period to review practice, but certain trends can be identified to date. First and foremost, it is clear that the Committee is prioritizing women's participation in peace processes and transitional justice processes in its monitoring of State activities. Given that this issue of participation is one of the four priority pillars of the WPS resolutions, it is noteworthy that it is the Committee, rather than the UNSC, that is pursuing meaningful accountability in this regard. The priority given by the Committee to women's participation is best illustrated by the selection of this issue for 'follow-up' by the Committee in Georgia, ${ }^{185}$ the Central African Republic, ${ }^{186}$ Iraq $^{187}$ and Syria. ${ }^{188}$ Further, NAPs continue to be an area of scrutiny. ${ }^{189}$ As specified in GR30, the Concluding Observations address

against Women, 'Concluding Observation to the Democratic Republic of Congo' (24 August 2006) UN Doc CEDAW/COD/CO/5, para 10.

${ }_{181}$ GR30 (n 3); for discussion, see O'Rourke (n 118).

182 GR30 (n 3) para 25 (emphasis added).

184 GR30 (n 3) para 83.

185 Committee for the Elimination of All Forms of Discrimination against Women, 'Concluding Observations to Georgia' (24 July 2014) UN Doc CEDAW/C/GEO/CO/4-5, paras 24, 25 and 42.

${ }^{186}$ Committee for the Elimination of All Forms of Discrimination against Women, 'Concluding Observations to the Central African Republic' (24 July 2014) UN Doc CEDAW/C/CAF/CO/1-5, paras 20(a) and 53 .

${ }_{187}$ Committee for the Elimination of All Forms of Discrimination against Women, 'Concluding Observation on Iraq' (10 March 2014) UN Doc CEDAW/C/IRQ/CO/4-6, paras 12 and 60.

${ }^{188}$ Committee for the Elimination of All Forms of Discrimination against Women, 'Concluding Observations on Syria' (18 July 2014) UN Doc CEDAW/C/SYR/CO/2, paras 14(a) and 53.

${ }^{189}$ Committee for the Elimination of All Forms of Discrimination against Women, 'Concluding Observations on Georgia' (24 July 2014) UN Doc CEDAW/C/GEO/CO/4-5, paras 24 and 25. The 
issues around statelessness, ${ }^{190}$ and employment and economic opportunities affected by conflict. ${ }^{191}$ Of particular interest are the Committee's Concluding Observations to Syria in 2014, which deal almost exclusively with conflictrelated challenges to women's human rights. The Committee draws heavily on GR30 to that end. It importantly draws attention to shortcomings beyond the State party, specifically around donor funding to the country ${ }^{192}$ and the conduct of non-State armed actors. ${ }^{193}$ To quote the Global Study on the Implementation of Resolution 1325 (2000), the Concluding Observations to Syria are a 'model for the engagement of civil society with human rights mechanisms on the WPS agenda'. ${ }^{194}$

From the perspective of the UNSC, by contrast, the potential for any synergy between its work and that of the human rights system has, thus far, been tentative. The WPS agenda and the wider thematic and routine work of the UNSC has continued to develop almost in isolation from obligations on women's rights and human rights in the wider UN system. Procedurally, this has meant little crossover in terms of accountability in respect of the UNSC itself with human rights mechanisms (such as the CEDAW Committee).

While the UNSC does reference broader normative and human rights instruments of the UN system in its resolutions, actual substantive engagement with the Convention has been sparse. Research undertaken for this article found that, between 1 November 2000 (after the adoption of resolution 1325) and 1 March 2016, the UNSC adopted 947 resolutions. Of these, 10 mention the Convention, six of which are WPS resolutions. ${ }^{195}$ Noteworthy is that the Convention is not referenced consistently in all of the WPS resolutions; it is even less consistent in the resolutions on CRSV. The Convention is cited in the operational paragraphs of Resolution 1325 (2000) and Resolution 2250 (2015), wherein States parties and parties to armed conflict are called upon to comply with applicable obligations under the Convention. It is further cited in Resolution 2145 (2014) and Resolution 2210 (2015) where duplicate requests are made to the UN mission in Afghanistan to continue support to that State's compliance to the Convention. Otherwise, where the Convention is mentioned, it appears in the preambular paragraphs, which are considered by some as a 'dumping ground' for proposals not

Committee called on State party to involve women in the implementation of its action plan; Committee for the Elimination of All Forms of Discrimination against Women, 'Concluding Observations on Syria' (18 July 2014) UN Doc CEDAW/C/SYR/CO/2, para 14(a).

${ }^{190}$ Committee for the Elimination of All Forms of Discrimination against Women, 'Concluding Observation to the Democratic Republic of Congo' (30 July 2013) UN Doc CEDAW/COD/CO/6-7, para 36(c). ${ }^{191}$ CEDAW (n 188) paras 41-42. ${ }^{192}$ ibid para 12. ${ }^{193}$ CEDAW (n 180).

194 Coomaraswamy (n 1) 357. The Committee issued strong and comprehensive concluding observations. These concluding observations could serve as a model for the engagement of civil society with human rights mechanisms on the WPS agenda.

195 Three resolutions on Afghanistan, Resolution 2120 (2013); Resolution 2145 (2014); Resolution 2210 (2015), and one resolution on youth, peace and security, Resolution 2250 (2015). 
acceptable in the operative paragraphs. ${ }^{196}$ It appears that, despite the apparent success in bringing feminism and women's rights concerns to the heart of the UNSC, the UNSC has nevertheless managed to compartmentalize its work on women, peace and security. This has led to fragmented approaches to supposedly universal guarantees of women's rights. It also poses important questions for the broader transformative demands that underpinned initial feminist civil society entry into the UNSC. ${ }^{197}$

\section{Proposed Institutional Interactions between CEDAW and the UNSC}

One of the key conclusions of the UNSC-mandated 2015 Global Study on the Implementation of Resolution 1325 was the need for improved synergies between international human rights mechanisms and the UNSC's WPS agenda. 198 With the adoption of GR30, the CEDAW Committee has provided practical guidance and a normative framework to that end. ${ }^{199}$ Against a backdrop of increasingly vocal concern about the form and substance of accountability mechanisms attendant to the WPS agenda, ${ }^{200}$ the international system for the protection of human rights has garnered renewed attention in efforts to enhance accountability for women's rights in conflict. If the potential for synergies is to be maximized, complementarity across the regimes (both substantively and procedurally) is required going forward. We outline some of the opportunities that exist in this respect. We do so with the caveat understanding that the mandates of each regime will determine and delimit their modal engagement. In addition, the political will of actors involved, particularly on the part of some UNSC permanent members who are resistant to connectivity with other UN institutional regimes, is likely to be the most critical factor in any success herein. Practically speaking, there are ways that the activity of each regime can be engaged with, shared and used to influence progress on women's rights in conflict by both regimes. These relate, principally, to the sharing of data, the pursuit of State-level accountability from both parties and non-parties to the CEDAW Convention, and the greater integration of women's human rights in the UNSC's interpretation of its mandate.

First, the data gathered by the CEDAW Committee through periodic and exceptional State party reports, civil society shadow reports and the Committee dialogue with State parties provide data that is of use to the UNSC as it makes decisions on situations on its agenda. The UNSC can rely on that data and demonstrate its willingness to make use of, and reference, that work in its own working methods. The Informal Experts Group of the UNSC established under Resolution 2242 (2015) has already made use of

\footnotetext{
196 MC Wood, 'The Interpretation of UN Security Council Resolutions' (1998) 2 MaxPlanckYrbkUNL 73, 86.

198 Coomaraswamy (n 90) $350 . \quad{ }^{199}$ GR30 (n 2). ${ }^{200}$ Coomaraswamy (n 90).
} 
reports by the CEDAW Committee in its briefing on Mali for example. ${ }^{201}$ This mechanism facilitates briefings to the UNSC about situations on its agenda that are delivered by experts and civil society organizations. This mechanism could also include the outputs of CEDAW State party monitoring activities. This is a particular opportunity for civil society, a constituency with considerably fewer opportunities for formal engagement with the UNSC than the CEDAW Committee, to have their insights and outputs considered. Likewise, the reports of peacekeeping missions and the UN Secretary-General's annual report on this issue could be shared with the CEDAW Committee, reinforcing joint reporting, data-sharing and approaches to addressing sexual exploitation within the UN system by both institutions. The opportunities that exist for enhanced data-sharing in the pursuit of improved overall accountability for women's rights in conflict are considerable.

Secondly, the CEDAW Committee and the UNSC offer distinctive opportunities in respect of State-level accountability for women's rights in conflict, due to differing institutional mandates and areas of authority. These opportunities can be maximized to common ends. The CEDAW Committee, for example, lends the non-discrimination and transformative end of women's rights provision to the overall agenda of the protection and advancement of women's rights in conflict and peacebuilding. Through its monitoring activities, the Committee can make recommendations that drive State-level implementation of WPS resolutions towards substantive equality and human rights for women. In addition, the CEDAW Committee drives accountability for WPS on States that are not experiencing conflict, but in line with GR30, have extraterritorial responsibilities in respect of thematic areas of WPS. ${ }^{202}$ Importantly, even member States that have thus far declined to report to the Secretary-General on WPS, and/or have not adopted NAPs, may still be held to account for their WPS commitments by the CEDAW Committee. Likewise, the UNSC can - through the Secretary-General's annual reporting on WPS - play a role in enhancing the State-level accountability of UN member States that are not party to the Convention, or rely on reservations to the Convention in order to avoid more substantive obligations concerning women's rights in conflict.

Thirdly, the UNSC can maximize the potential of its own areas of authority, by more comprehensively integrating women's human rights in the interpretation of its mandate. For example, a High-Level Review of the UNSC's sanctions regime in 2014 made specific recommendations for expanded sanctions criteria that would allow thematic areas of concern to be considered as 'threats' under the UNSC's mandate in respect of sanctions. This included a recommendation that the UNSC 'should use existing

201 Statement by UN Women Deputy Executive Director for Policy and Programme, Yannick Glemarec, Arria Formula Meeting on Linkages between Security Council Resolution 1325 and CEDAW GR 30 (5 December 2016).

202 GR30 (n 2). 
sanctions regimes more effectively to enforce thematic priorities, including ... the Women, Peace and Security Agenda[s]'. ${ }^{203}$ A further recommendation was made to adopt thematic sanctions regimes that would include not only sexual violence (which has been its only focus to date as noted before) but also significantly 'gross violations of women's rights'. ${ }^{204}$ Whether and how women's rights violations reach the threshold of 'threat' to international peace and security remains to be seen. The sanctions committee can, for example, make use of States parties' reports and concluding observations of the CEDAW Committee, drawing in data from the CEDAW Committee in order to inform its decisions-making.

Divergent approaches and accountability mechanisms not only counter the potential of these provisions, but they also entrench the challenges that both bodies of instruments face. Pursuing the complementary operation and implementation of both regimes is critical. In a world of changing modalities and conceptualizations of armed conflict and terrorism, there is more than ample impetus to work with and through the historical divisions across the UN systems.

\section{CONCLUSION}

While a specifically 'feminist' position on fragmentation in international law is unlikely, sustained consideration of the practical institutional implications of overlapping gender equality norm development is a critical area of inquiry. This article has sought to investigate the overlapping thematic activity on women's rights in conflict, but also to offer a methodology for similar investigations in other thematic areas of relevance. The feminist project in international law has always been one of both process and substance. ${ }^{205}$ Thus we conclude with some reflections on the optimum forward trajectory of the institutional interactions between the CEDAW Committee, as an institution of human rights law, and the UNSC, by advocating processes of both crossregime dialogue and inter-regime accountability. We believe these reflections have relevance for those concerned with fragmentation in international law and for those concerned with the efficacy of gender equality norm development under international law.

The adoption of concurrent provisions on women and conflict by both the CEDAW Committee and the UNSC has brought these two entities into direct conversation with each other, albeit from different legal, normative and mandate-driven standpoints. The CEDAW Committee, through GR30, has provided guidance to States on their obligations to women's rights in settings of conflict and peacebuilding. The WPS resolutions have ensured that the UNSC is engaged in institutional activity regarding women's rights within its

203 UNGA and UNSC (n 148) 68, Recommendation 132.

205 See further Charlesworth, Chinkin and Wright (n 8).

204 ibid. 
mandate, such as using its specific powers to address issues like CRSV through its sanctions regime. For both regimes, it is evident that moving forward on modalities for the practical enforcement and implementation of the concerns and rights of women in conflict cannot be advanced in isolation from the other. Here we see an important role for cross-regime dialogue.

Cross-regime dialogue should also be seen, however, as a means to advance an ongoing process of inter-regime accountability, in which each seeks to hold the other to account for its activities on women's rights in conflict. In the increasingly complex terrain of international law, proposals for regime interaction need to be contextual and institution-specific, and judged with respect to the democracy, transparency and openness of the respective institutions. Proposals that maximize accountability (broadly understood) will also contribute to legitimacy. This is something that should motivate both regimes. Rather than seeing the differences in mandate and focus as obstacles to the advancement of women's rights, it is important to recognize the value in tensions between the security-focus of the UNSC and the feminist and rightsbased approach of the CEDAW Committee.

Consider for example, the Arria Formula meeting between the UNSC and CEDAW Committee, the very first such meeting between the UNSC and a treaty-based human rights monitoring committee of the UN system. ${ }^{206}$ The meeting was held in public and was thus strong on transparency. It constituted an opportunity for the UNSC member States to probe and challenge the CEDAW Committee's interpretation of the WPS resolutions, as well as the binding nature of the CEDAW Committee's interpretative activities, such as developing general recommendations. ${ }^{207}$ Likewise, the CEDAW Committee challenged UNSC member States to implement their human rights obligations through their UNSC membership, and to avoid treating the two as discrete activities. ${ }^{208}$ More routinely, the CEDAW Committee retains the opportunity to review and challenge the substance and scope of WPS activities of CEDAW State parties and UN country offices through periodic State examination, which it has shown great willingness to do. Similarly, in his 2016 Annual Report to the UNSC on Women, Peace and Security, the Secretary-General made specific recommendations to the CEDAW Committee about how they might advance implementation of the WPS agenda. ${ }^{209}$ We see - in these spaces of challenge, tension and contestationthe opportunity for the respective regimes to advance a continual process of constructive cross-regime dialogue and inter-regime accountability.

\footnotetext{
206 S Daws and L Sievers, Arria-Formula Meetings, 1992-2016 (Security Council Report 2016).

207 Statement by Egypt, Arria Formula Meeting on Linkages between Security Council Resolution 1325 and CEDAW GR 30 (5 December 2016).

208 Statement by Pramilla Patten, Arria Formula Meeting on Linkages between Security Council Resolution 1325 and CEDAW GR 30 (5 December 2016).

209 Report of the Secretary-General on Women, Peace and Security (2016) UN Doc S/2016/822, para 73.
} 